\title{
MARÂIWATSÉDÉ, UMA TRAGÉDIA ANUNCIADA
}

\author{
PATRÍCIA DE MENDONÇA RODRIGUES ${ }^{1}$
}

Universidade de Chicago

\begin{abstract}
RESUMO: A história dos Xavante setentrionais, os A'uwê de Marãiwatsédé, está entre os casos mais graves de violação de direitos humanos do Relatório da Comissão Nacional da Verdade. Embora a sua "pacificação" tenha se iniciado antes, em outro contexto político, a transferência forçada do povo de Marãiwatsédé e a subsequente e impactante morte de dezenas de pessoas ocorreram durante a ditadura militar, por meio de uma aliança entre grupos econômicos poderosos e o poder público. O trauma gerado naquela época se perpetuou nas novas gerações $e$ até hoje não foi plenamente digerido pelo povo Xavante. $O$ artigo traz a público, de modo inédito, parte central dos relatos dos próprios A'uwê sobre as violências ocorridas na década de 1960, que estão no Relatório de Identificação da Área Indígena Marãiwatséde, o documento pioneiro da Funai que deu sustentação sólida ao reconhecimento oficial da Terra Indígena Marãiwatsédé pelos poderes executivo e judiciário.
\end{abstract}

PALAVRAS-CHAVE: Xavante de Marãiwatséde; genocídio; ditadura militar; resiliência.

ABSTRACT: The history of the northern Xavante, known as the A'uwê of Marãiwatsédé, is among the most serious cases of human rights violation in the Report of the Brazilian National Truth Commission. Although their "pacification" had begun before, in another political context, the forced removal of the people from Marãiwatsédé and the subsequent and shocking death of dozens of people occurred during the military dictatorship in Brazil, through an alliance of powerful economic groups and the public power. The trauma generated at that time continued for several generations and has not been fully assimilated by the Xavante. The present article brings to the public in an unprecedented way a central part of the Xavante narratives about the violence experienced in the 1960s. The oral narratives are in the official report of Funai, Relatório de Identificação da Área Indígena Marãiwatséde, the pioneer document which gave solid support to the official recognition of the Marãiwatsédé Indigentous Land by Brazilian government and the judiciary.

KEYWORDS: Xavante of Marãiwatsédé; genocide; military dictatorship; resilience.

\footnotetext{
${ }^{1} \mathrm{PhD}$ em Antropologia pela Universidade de Chicago (EUA), coordenou o grupo técnico da Funai que identificou a Terra Indígena Marãiwatsédé, com a colaboração da antropóloga Iara Ferraz e do ambientalista Mariano Mampieri. Realiza pesquisa com povos do Araguaia (Javaé, Karajá, Xavante, AváCanoeiro) desde 1990 e coordenou vários outros grupos técnicos de identificação de terras. E-mail: dituhe@ hotmail.com .
} 


\section{Uma história impactante}

As violências cometidas contra os Xavante setentrionais, conhecidos como os A'uwê de Marãiwatsédé2, e os Avá-Canoeiro do Araguaia (RODRIGUES, 2012, 2013a), ambos habitantes tradicionais do médio Araguaia e vítimas do mesmo processo brutal de transferências forçadas para a terra de outros e de apropriação de seus territórios, estão entre os casos mais graves de violação dos direitos humanos do Relatório da Comissão Nacional da Verdade (2014). Os fatos ocorridos nas décadas de 1960 e 70 com esses dois povos durante os governos militares são uma espécie de ápice trágico de um longo processo de opressão e guerra colonial no Brasil Central, em que os dois grupos de famosos e resistentes guerreiros sofreram uma derrota traumática e de consequências duradouras, sendo condenados ao exílio, ao confinamento e à marginalização social e econômica por décadas. Até então, apesar de séculos de enfrentamentos e sofrimentos variados, havia uma relativa autonomia territorial, social, política e econômica que foi fraturada mortalmente nesse período da ditadura militar, que promoveu o avanço de grandes grupos empresariais do sul e sudeste sobre vastas áreas de territórios indígenas da Amazônia Legal. Os Xavante de Marãiwatsédé e os Avá-Canoeiro do Araguaia sofreram uma ruptura radical em sua trajetória histórica e passaram à condição de derrotados de guerra.

Os atuais povos do médio Araguaia, os Xavante, os Karajá, os Javaé, os Tapirapé e os Avá-Canoeiro, impressionam pesquisadores pela capacidade de resiliência física e cultural. São todos sobreviventes incansáveis da captura e escravização promovidas pelos bandeirantes nos séculos XVI e XVII, da política repressora dos aldeamentos e prisões dos séculos XVIII e XIX, das grandes mortandades provocadas pelas epidemias desconhecidas, da Marcha para o Oeste, da Expedição Roncador-Xingu, da política indigenista de "pacificação", transferências e sedentarização, da ditadura militar e da invasão crescente de seu território pelas frentes de expansão econômica que se transformaram no atual agronegócio.

Entretanto, tudo na história dos A'uwê de Marãiwatsédé é superlativo. O povo é retratado como um dos mais aguerridos na

\footnotetext{
${ }^{2}$ Nome da região específica habitada pelos Xavante setentrionais, traduzido como "mato geral, do lugar, a mata" da região (Rodrigues, Ferraz e Manpieri, 1992:1).
} 
literatura histórica e cujo longo processo de "pacificação" foi um fenômeno de mídia nas décadas de 1940 e 50: a extensão gigantesca da fazenda que se instalou em suas terras, tida como o maior latifúndio do Brasil na década de 1970, quando atingiu cerca um milhão de hectares, impulsionada por um projeto de pecuária falido que recebeu o maior financiamento da história da SUDAM; a ascensão extraordinária da família Ometto e seu império sucroalcooleiro, proprietária da Fazenda Suiá Missú, que de imigrantes italianos em situação de miséria no fim do século XIX, tornaram-se os maiores produtores de álcool do mundo na década de 70; a associação entre os Ometto e Ariosto da Riva, também descendente de imigrantes italianos, que implantou cidades inteiras no Mato Grosso com seus projetos privados de colonização; a inacreditável transferência dos índios em aviões da FAB em 1966 para uma área a mais de $500 \mathrm{~km}$ de distância, a partir de uma articulação perversa entre poderosos fazendeiros, o ministro da Aeronáutica, o órgão indigenista e missionários salesianos; a venda da terra para a AGIP na década de 70 , uma multinacional italiana do petróleo com participação estatal; a articulação entre os Xavante e ONGs socioambientalistas para a constituição de um Grupo Técnico da Funai com o objetivo de identificação da terra indígena na década de 90. A promessa midiática e não cumprida dos dirigentes italianos da AGIP em plena ECO-92 de devolver o território indígena aos seus ocupantes originais; um novo erro da Funai ao desmembrar a área identificada entre a parte a ser reconhecida imediatamente (a que era ocupada pela multinacional), e a que seria reconhecida "depois" (o que não ocorreu ainda); uma associação criminosa entre grupos empresariais, fazendeiros, advogados, autoridades locais e políticos da bancada ruralista, que invadiram Marãiwatsédé em 1992 sob o argumento racista de que era melhor entregar a terra a qualquer um do que devolvê-la a índios; a transformação de Marãiwatsédé pelos invasores na terra indígena mais degradada do Brasil em 2010; a demarcação e a homologação da terra indígena pela Funai com os Xavante morando fora da área; uma longa batalha judicial entre o MPF e os invasores de má-fé, que financiaram laudos falsos e fomentaram a discórdia entre os A'uwê; a vitória da causa xavante em todas as instâncias judiciais; a volta dramática dos A'uwê ao seu território original em 2004 , depois de quase 40 anos de persistência 
e diante da resistência física dos invasores; o apoio das organizações ambientalistas e indigenistas à extrusão da terra indígena na Rio+20; um processo estrondoso de desocupação dos invasores da terra em 2012/2013, no governo Dilma Rousseff, acompanhado de uma nefasta manipulação dos fatos pelos meios de comunicação; uma Ação Civil Pública do $\mathrm{MPF}^{3}$ em 2016 contra a União, a Funai, o estado do Mato Grosso e os herdeiros das famílias Ometto e da Riva pelo crime de genocídio, pedindo uma indenização por danos morais e materiais, entre várias outras medidas relevantes, de cerca de centro e trinta milhões de reais, em favor dos Xavante de Marãiwatsédé.

Pode-se argumentar que, em certo sentido, a história de Marãiwatsédé sintetiza o modo como foi feita a colonização do país, deixando como legado a extraordinária resiliência étnica dos A'uwê, que vivenciaram não a redenção prometida pelos missionários, mas 0 apocalipse com o avanço do capitalismo para o interior do Brasil. O modo ora negligente ora traiçoeiro de como o processo de expropriação da terra foi conduzido pelo Poder Executivo durante a ditadura militar, em aliança com as elites econômicas, também deixou como herança um ódio racista e genocida de grande parte da população local em relação aos Xavante, que hoje insistem em retomar sua vida tradicional no espaço degradado e hostil em que se transformou seu antigo território.

Essa história tem sido abordada em vários trabalhos recentes, contemporâneos ao relatório da CNV, como o trabalho de Deluci e Portela (2013), a dissertação de mestrado em história de Juliana Cristiana da Rosa (2015), a tese de doutorado em desenvolvimento sustentável de Armando Wilson Tafner Júnior (2015), o livro sobre a ditadura militar e os povos indígenas do jornalista Rubens Valente (2017), a dissertação de mestrado de Cosme Rite (2017), Xavante de Marãiwatsédé, e o laudo pericial de Paulo Tavares (2017) para o MPF na ação de indenização. Anteriormente, os trabalhos mais significativos foram os textos-denúncia da antropóloga lara Ferraz (1990) e do ambientalista Mariano Mampieri (FERRAZ; MAMPIERI, 1996), que foram os principais ativistas da campanha internacional pela devolução do território xavante, e o laudo pericial decisivo da antropóloga Inês Rosa Bueno (2006) no processo judicial que culminou com o retorno dos Xavante a Marãiwatsédé.

${ }^{3} \mathrm{~N}^{\circ}$ 2766-51.2016.4.01.3605, Justiça Federal de Barra do Garças (MT). 
O presente artigo traz a público parte central dos relatos dos próprios A'uwê sobre as violências ocorridas na década de 1960, que estão no Relatório de Identificação da Área Indígena Marãiwatséde (RODRIGUES; FERRAZ; MAMPIERI, 1992), o documento pioneiro da Funai, referido por todos os trabalhos mencionados, que deu sustentação sólida ao reconhecimento da Terra Indígena Marãiwatsédé pelos Poderes Executivo e Judiciário. O relatório foi objeto de grande polêmica por parte dos invasores da terra indígena, repercutida pela mídia local, mas foi amplamente corroborado pelos laudos periciais de Bueno (2006) e Tavares (2017).

\section{A invasão do território xavante}

Os "Xavante", termo genérico que encobre subdivisões étnicas, falantes de uma língua Jê e autodenominados A'uwê, são referidos na literatura histórica e antropológica como um povo valente que resistiu aguerridamente à violência da colonização durante séculos, como no clássico estudo de Maybury-Lewis (1984). Os registros históricos e a memória oral do grupo revelam que eles estavam habitando o norte da antiga Capitania de Goiás, entre os rios Tocantins e Araguaia, até o início do século XIX, quando então se subdividiram em meio aos conflitos com os colonizadores. Parte do grupo se deslocou rumo ao sul e atravessou o Rio Araguaia ao sul da llha do Bananal, atingindo definitivamente a região do seu principal afluente, o Rio das Mortes, na primeira metade do século XIX. Um relatório oficial de 1855 relata a expedição fluvial que o missionário capuchinho Frei Segismundo de Taggia realizou ao Rio das Mortes no ano anterior, acompanhado de índios Karajá e Xavante, conseguindo manter contato com uma distante aldeia Xavante (CRUZ MACHADO, 1997; SPÍNDOLA, 2001).

As terras da margem esquerda do Rio Araguaia em seu médio curso ficaram conhecidas regionalmente como "o temido território xavante" até a década de 40 do século XX. Segundo a memória dos próprios A'uwê e de povos vizinhos, como os Tapirapé (WAGLEY, 1988) e os Karajá (TORAL, 1992), vários subgrupos xavante passaram a ocupar uma vasta área na região do Rio das Mortes e da Serra do Roncador, em suas expedições de 
caça, pesca e coleta, que tinha o Rio das Garças como limite ao sul, o Rio Tapirapé ao norte, o Rio Xingu a oeste e o Rio Araguaia a leste, mantendo contatos amigáveis ou conflituosos com os povos dessas regiões, como os Bororo, os Kalapalo, os Kayapó, os Karajá e os Tapirapé. Existiam várias aldeias xavante espalhadas estrategicamente na região, de forma a impedir a invasão de outros grupos.

$\mathrm{Na}$ primeira metade do século $\mathrm{XX}$, inúmeros exploradores, comerciantes, funcionários públicos, pesquisadores, missionários e jornalistas aventuravam-se pelo Rio Araguaia e nas aldeias karajá, mas evitavam a região do Rio das Mortes ${ }^{4}$, assim chamado por causa da carnificina de índios Araé e Karajá cometida pelo afamado bandeirante Antônio Pires de Campos no século XVII (ALENCASTRE, 1864). Nas décadas de 1930 e 40, houve expedições de aventureiros e tentativas fracassadas de contato dos Xavante por parte de missionários salesianos, como Pierre Sacilotti e Jean Baptiste Fuchs, em 1934, e funcionários do SPI, como Pimentel Barbosa, em 1941, mortos durante as tentativas (DUROURE, 1936; MAYBURY-LEWIS, 1984). Pequenos colonos começavam a se instalar nas margens do território xavante e a entrar em conflitos com os índios, que em alguns casos acabaram procurando proteção nas missões salesianas.

Em 1940, o presidente Getúlio Vargas fez uma visita à aldeia karajá de Santa Isabel, no Rio Araguaia, a mais próxima das aldeias interioranas dos A'uwê de Marãiwatsédé, onde ficou por cinco dias em um acampamento de caça e pesca. Essa visita histórica deu o impulso definitivo à criação da Expedição Roncador-Xingu, que "tinha a finalidade de abrir vias de comunicação do litoral com o Centro-Oeste e a Amazônia" (LIMA FILHO, 2001, p. 41). Vargas sobrevoou o Rio das Mortes e o território xavante acompanhado de representantes da imprensa, do padre salesiano Chevelon e do chefe Karajá Watau (ARTIAGA, 1959; PINHEIRO, 1994).

O Araguaia foi escolhido para ser o ponto de partida do movimento de interiorização do país conhecido como a Marcha para o Oeste (VILLAS BÔAS; VILLAS BÔAS, 1994), lançado por Vargas em 1938 e depois retomado por Juscelino Kubitschek, com a construção de Brasília. Em 1943, o governo criou a Fundação Brasil Central (FBC), cujo objetivo era

\footnotetext{
${ }^{4}$ Por exemplo, Aureli (1962a, 1962b), Tilbor Sekelj (1948).
} 
o desbravamento e a colonização da região do Araguaia e Xingu. A FBC foi responsável pela estrutura de apoio da Expedição Roncador-Xingu, comandada em campo pelos irmãos Villas-Bôas, que partiu no mesmo ano de Aragarças, nas margens do Araguaia, rumo ao Rio das Mortes e à Serra do Roncador, abrindo o caminho para a colonização efetiva do território xavante.

A cidade de São Félix do Araguaia, importante centro regional do médio Araguaia, fundada em 1941, nas proximidades de Marãiwatsédé, foi batizada pelo dominicano Dom Sebastião Tomás em homenagem ao santo invocado pelos moradores locais para protegê-los justamente dos ataques xavante (ver FERREIRA, 2001; LIMA FILHO, 2001). Os antigos moradores da cidade têm uma memória detalhada sobre as expedições de caça aos índios de Marãiwatsédé que foram feitas nas décadas de 40 e 50 e das retaliações feitas pelos Xavante. Na década de 50, os posseiros e pequenos fazendeiros tinham medo de ir para além das redondezas do vilarejo por conta da presença dos índios. Raimundo Aleixo Borges, que morou na Serra do Roncador e em São Félix do Araguaia, e tinha 15 anos quando trabalhou na abertura de picadas da Fazenda Suiá Missú, lembrou em 1992 com detalhes dessa época. Na década de 50, o Rio Xavantinho, afluente do Rio Tapirapé, era o divisor natural entre a terra dominada pelos índios, a oeste do rio, e a região onde a população de São Félix começava a se expandir, a leste.

Eles matavam porque os índios... como que chama esse pessoal? Migrantes. Eles vão tomando as terras, porque os índios mandavam de São Félix para lá. Lá só tinha índio, não tinha cristão lá. Aí foi povoando, começou a fazer esses povoadinhos, sabe? Aí os índios atacavam. Atacaram São Félix, atacaram as fazendas. Então o pessoal foi entrando, entrando. Os índios atacavam, eles juntavam um grupo e atacavam os índios. Aí ia entrando mais. Os índios tornavam a atacar. Mas até que os índios mexiam mais se eles fizessem qualquer grosseria com eles. O [Rio] Tapirapé, o Xavantinho, o Gameleira, as cabeceiras do Xavantinho, aquilo tudo era habitado só por índios, só tinha índio, índio que mandava ali tudo. Nessa época de 58 e 59, só tinha gente até ali a beira do [Rio] Xavantinho, certeza! Depois, os primeiros migrantes que foram entrando fomos nós. Não tinha ninguém ali, era só índio mesmo. Te digo até o nome das pessoas que tinha na beira do Xavantinho. Tinha 0 
Antônio Silva, Zé Joaquim, mais embaixo o velho Amâncio de Melo. Lá mais para baixo tinha gente na Serra de Magalhães, tinha a família dos Campo. Por acima tinha o velho Natávio e outros moradores. Tinha poucos, mas só na beira do Xavantinho. Do Xavantinho para cá [oeste], não tinha ninguém. Eles tinham medo de entrar (BORGES apud RODRIGUES; FERRAZ; MAMPIERI, 1992, p. 30).

A família dele fez parte do "primeiro grupo a passar do Xavantinho", instalando-se nas proximidades do Córrego Capuxu. Com medo, as cerca de vinte famílias moravam agrupadas e faziam "a roça tudo junto", "porque tinham medo dos índios. [Eles] andaram visitando, mas nunca mexeram com a gente não". Segundo essa memória, as aldeias xavante estavam na Serra do Roncador, na zona de transição entre o cerrado e a mata. As expedições punitivas organizadas pela população de São Félix do Araguaia já haviam cessado quando os primeiros moradores cruzaram o Rio Xavantinho, mas até a década de 50 houve conflitos.

Tinha esses grupos que organizavam para matar os índios quando os índios atacavam eles. Era aquele pessoal mais velho. Eles moravam tudo perto de São Félix mesmo. Não moravam muito para cá não, sabe. Nem na beira do Xavantinho não era, era mais para lá. Isso é coisa de muitos anos atrás. Quando a Suiá entrou para cá, aí não existia mais esse negócio de matança de índios. Diz que eles juntavam em grupo e atacavam. Geralmente não iam nas aldeias. Eles saíam e onde encontravam, como nessas cabeceiras do [córrego] Grotão mesmo, teve lugar que eles mataram muito índio lá. Era perto das aldeias dos índios. Eles chegavam, achavam os índios caçando por ali ... o índio não fica na aldeia, ele fica um tempo, mas ele sai e faz as barraquinhas aqui, acolá, fazem as barraquinhas deles para caçar. Dali ele vai até quando chega um tempo e eles voltam tudo de novo para a aldeia. Então, aonde eles encontravam esses agrupamentos deles, eles atacavam e matavam. [...] Esse pessoal que atacava os índios, acho que já morreu quase tudo. Quando eu conheci, nessa época eu tinha 15 anos, eles já eram tudo de idade, bem velhos. Morreu família, muita gente dos cristãos e dos índios também. Isso eu sei porque eles contavam, um contava para o outro, eu ouvia, às vezes não contava direto para mim, contava para outro, mas eu ouvia. Isso foi talvez no final da década de 40 para 
50 (BORGES apud RODRIGUES; FERRAZ; MAMPIERI, 1992, p. 32).

Raimundo se lembrou do famoso massacre da família de João Irineu pelos Xavante, mencionado nos relatórios do SPI.

Mataram a família dele inteira. Foi nessa época que eles atacavam os índios também. Os índios sempre estavam ali perturbando. Um cara pegou e jogou mel quente no índio. Aí os índios juraram eles. Vieram, só escapou uma menina e um rapaz (BORGES apud RODRIGUES; FERRAZ; MAMPIERI, 1992, p. 3).

O SPI continuou tentando o contato com os Xavante, que eram o grande obstáculo na rota da Expedição Roncador-Xingu, até que o sertanista Francisco Meireles se tornou célebre pela "pacificação" dos mesmos entre 1946 e 1953 (VALENTE, 2017). Na ideologia da "pacificação" que norteou a política indigenista desde a fundação do SPI, as relações de "paz" não significavam o estabelecimento de relações de reciprocidade igualitárias e harmônicas entre diferentes, mas o lugar de perdedor, periférico e subalterno, para aquele que foi "pacificado" na guerra de conquista pelo colonizador. O contato não incluiu, entretanto, os Xavante mais setentrionais de Marãiwatsédé, que continuaram em conflitos sangrentos com pequenos posseiros e fazendeiros até a instalação da Fazenda Suiá Missú no início da década de 60.

Desde 1950, o servidor do SPI, Ismael Leitão, que atuava no Posto de Atração Pimentel Barbosa, solicitou por várias vezes, sem sucesso, a instalação de um posto de atração para o grupo, que aparecia esporadicamente nas imediações do vilarejo de São Félix do Araguaia, causando "um alvoroço tremendo". Em seus relatórios da década de 50 , Ismael Leitão falava de "aldeia de Maroaced, com 25 malocas" (apud RODRIGUES; FERRAZ; MAMPIERI, 1992, p. 23) e de invasões e agressões crescentes ao território indígena. Em seu depoimento à antropóloga lara Ferraz (RODRIGUES; FERRAZ; MAMPIERI, 1992), ele lembrou que cinco índios ficaram por cerca de um mês na fazenda de João Irineu, o delegado de polícia de São Félix, que logo entrou em atrito com os mesmos, tentando "furar a barriga" de um deles, pois queria que os Xavante trabalhassem para ele. Foi nessa oportunidade que o inspetor entrou em contato com os Xavante de Marãiwatsédé, por meio de um intérprete 
Xerente, acertando a instalação de um posto no Riozinho. Nesse intervalo, ocorreram desentendimentos com os índios que levaram à morte do fazendeiro Pedro Tapirapé e da família de João Irineu, o que inviabilizou a instalação de um posto nas proximidades do povoado. Raimundo Borges se lembra das conversas com os índios por meio de um Xerente.

\begin{abstract}
Esses índios já tinham sido conversados por um Xerente chamado Caetano, que vinha de lá conversar com esses índios aqui, de lá de São Félix. [...] Só conheci ele e o filho dele. [...] Era ponto deles dormir lá em casa, pra cá de São Félix. (Eu) morava no São Sebastião [atual Chapadinha]. Então ali era a estrada deles. Eles dormiam ali e dali esses vinham aqui para a Serra. [...] Eles vinham e conversavam com os índios. Foram domando os índios, foram domando (BORGES apud RODRIGUES; FERRAZ; MAMPIERI, 1992, p. 36).
\end{abstract}

Em 1956, um antigo encarregado da Fundação Brasil Central, da base em Xavantina, já procedia à demarcação de terras de "sua propriedade" na margem esquerda do Rio das Mortes, na localidade chamada Córrego dos Patos, em pleno território xavante, fato comunicado por Ismael Leitão ao diretor do SPI. Em 1957, os índios de Marãiwatsédé fizeram o primeiro contato amistoso com o servidor no Posto Indígena Pimentel Barbosa, "quando narraram a invasão de suas terras por aventureiros em busca de pedras preciosas, bem como o trucidamento de dois índios" (apud RODRIGUES; FERRAZ; MAMPIERI, 1992 p. 24). No mesmo ano, Ismael Leitão denuncia a tentativa de apropriação das terras dos índios por um estrangeiro de nacionalidade húngara, que demarcou glebas nas proximidades da "aldeia de Maru-Acéde", onde estava "radicado um grupo arredio de índios Xavante". As invasões continuaram aumentando, mas nenhuma providência foi tomada pelo SPI ou pelo governo estadual. Leitão continuou insistindo na necessidade de fundação de um posto para os índios de Marãiwatsédé em documentos oficiais até que, em 1960, ele denuncia a chegada de topógrafos para medir as terras vendidas pelo estado do Mato Grosso.

Segundo os A'wuê, a principal aldeia da região de Marãiwatséde era Bo'u ("urucum"), o centro de outras aldeias da região, como Ub'donho'u ("capivara"), Tsib'to'mo'tsé ("olho vermelho") e Tsé (perto do Rio Tapirapé), situadas na área entre as cabeceiras do Rio Xavantinho, nome 
dado em função da presença indígena, e o Rio Tapirapé, que cai no Araguaia. Quando os invasores começaram a chegar, matando muitos Xavante, os habitantes dessas aldeias se dispersaram e fundaram outras aldeias menores, como Ete'tsimã'rã (um tipo de morro, situada perto do alto Rio Tapirapé), Ire'pa (“barreiro”), U’dzu'rã’wawe (“local com muito buriti") e Monipa ("lugar de muito inhame"), onde também foram alvos de ataques. Houve, porém, contatos pacíficos com alguns colonos, como nas imediações de Ete'tsimã'rã, onde morava “Tibúrcio, o primeiro morador de quem os Xavante tiveram apoio para arrumar mandioca, farinha, todas essas coisas" (RAUL apud RODRIGUES; FERRAZ; MAMPIERI, 1992, p. 53). O cacique de Ire'pa, que aprendeu um pouco de português e intermediou o contato com os brancos, ficou conhecido depois pelo nome Tibúrcio.

\section{A violência dos latifúndios}

Na década de 1950, aumentou a penetração das frentes pastoris e agrícolas no médio Araguaia, em ambas as margens, tanto em função da "pacificação" dos Xavante como dos efeitos da Marcha para o Oeste. As construções de Goiânia nos anos 30 e a de Brasília no fim da década de 50 inauguraram um novo fluxo migratório no Brasil Central, com a instalação de grandes fazendas nas duas margens do Araguaia. A Ilha do Bananal e o Araguaia também foram considerados pelo governo de Juscelino Kubitschek (1955-1960) como pontos estratégicos para o processo maior de ocupação do interior do país e de construção da brasilidade (LIMA FILHO, 2001). Assim como Getúlio Vargas, o presidente também visitou a aldeia karajá de Santa Isabel, em 1960, para expedições de caça e pesca, e logo a seguir foi deflagrada a Operação Bananal. Em poucos meses, a Fundação Brasil Central foi encarregada de construir ao lado da aldeia o Hotel JK, projetado por Oscar Niemeyer, uma grande pista asfaltada para aviões, uma base militar da Força Aérea Brasileira, um hospital indígena, uma escola primária e a residência oficial onde Juscelino e sua comitiva se hospedavam em suas expedições de caça e pesca. A invasão de várias centenas de trabalhadores ao local impactou diretamente os Karajá e também os mais distantes Xavante de 
Marãiwatsédé. Foi dessa pista de avião em Santa Isabel que partiu o avião da FAB que removeu os Xavante de seu território poucos anos depois.

Os conflitos entre índios, campesinos e grandes propriedades rurais teriam início a partir de 1959, depois que o estado do Mato Grosso, por meio da CODEMAT, colocou à venda imensas áreas do território tradicional dos Xavante, Karajá e Tapirapé, consideradas devolutas, a grandes proprietários do sul/sudeste, com o objetivo de colonização do interior pela frente agropecuária 5 . Em 1954, a Companhia Imobiliária do Araguaia (CIVA) instalou-se em Santa Terezinha, ao norte de São Félix do Araguaia, obtendo concessão para explorar uma extensa área no Mato Grosso (CARDOSO DE OLIVEIRA, 1959). A CIVA foi dissolvida e, em 1960, o estado de Mato Grosso vendeu 1.200.000ha na região a uma companhia de investimentos de São Paulo. A área enorme - onde estavam aldeias dos Tapirapé e Karajá, um posto do SPI, pequenos posseiros e o povoado de Santa Terezinha - foi vendida a outras empresas em 1961, como os grupos BCN (Banco de Crédito Nacional), CODEARA (Companhia de Desenvolvimento do Araguaia), Tapiraguaia S/A e Porto Velho (IAP Agropecuária) (ver ESTERCI, 1987).

Após o golpe de 1964, como mostra o jornalista Rubens Valente (2017, p. 25) em seu recente livro sobre a ditadura militar e os povos indígenas, baseado em análise de documentos que permaneceram secretos até 2012 , os militares deram continuidade ao antigo plano de "ocupação" da Amazônia. Considerada erroneamente como um grande deserto verde, lançaram a "Operação Amazônia" em 1966, mesmo ano da criação da Superintendência do Desenvolvimento da Amazônia (SUDAM). Um verdadeiro genocídio foi posto em marcha pelo Estado brasileiro e violências variadas foram cometidas e mantidas ocultas em documentos oficiais secretos nesse processo de conquista do território mediado por ações denominadas de "pacificação", em que os povos indígenas eram percebidos e tratados como entraves ao progresso nacional.

$\mathrm{Na}$ época, a política indigenista patrocinava transferências e a sedentarização dos grupos em sua busca insana pela "integração" dos povos indígenas à nação. Essa política equivocada sempre esteve atrelada aos interesses econômicos e foi agravada nos governos militares. Assim, em conjunto ou não com as frentes de atração, procedimentos como

${ }^{5}$ Ver Wagley (1988), Esterci (1987), Escribano (2000), Rodrigues (2013b), Tafner Júnior (2015). 
transferência forçada para terras distantes de má qualidade, territórios de povos adversários ou presídios, confinamento, contaminação em massa com doenças desconhecidas e mortais, por negligência e omissão, entre muitos outros, foram recorrentes e resultaram na perda de autonomia dos povos originários e na invasão e devastação de grande parte das terras indígenas de ocupação tradicional. Embora a "pacificação" dos Xavante tenha se iniciado antes, em outro contexto político, a transferência forçada dos Xavante de Marãiwatsédé, os últimos a serem contatados, se deu durante a ditadura militar, por meio de uma aliança entre grupos econômicos poderosos e o poder público.

A iniciativa incluía a abertura de linhas de financiamento e generosos incentivos fiscais da SUDAM a grandes empreendimentos na Amazônia Legal, os quais foram estimulados a explorar economicamente vastos territórios indígenas. Foram beneficiados por essa política latifúndios que ficaram negativamente famosos pelas violências cometidas contra índios e posseiros, como os listados a seguir.

A Fazenda Suiá Missú6 foi o primeiro latifúndio "escriturado" que se instalou na região de São Félix do Araguaia, atraindo um grande número de trabalhadores rurais para suas atividades de aberturas de picadas, iniciadas em 1961, desmatamento e pecuária. Tornou-se famosa não só pela violência com que seus proprietários trataram os peões da fazenda, tendo expulsado posseiros e os Xavante de Marãiwatsédé para se apropriar de suas terras, mas também por ter se tornado o maior latifúndio brasileiro nos anos 70. Esse padrão de violência se repetiu na vizinha Fazenda CODEARA (ESTERCI, 1987), que devido ao modo brutal com que lidava com seus empregados, ficou conhecida pela própria Polícia Federal como um "ninho de escravidão branca", "o maior caso de escravidão de toda a história do Brasil" (CASALDÁLIGA apud ESCRIBANO, 2000 p. 64). A Fazenda Canuanã - dos irmãos paulistas Pazzanese, na margem direita do Araguaia, que tinha uma área registrada de 100.000ha, mas se apropriou ilegalmente de extensões muito maiores, expulsando posseiros -, por sua vez, ordenou ataques de vaqueiros aos Avá-Canoeiro, além de destruir um importante cemitério javaé e se apoderar das terras desses dois grupos (RODRIGUES, 2010, 2012, 2013a).

\footnotetext{
${ }^{6}$ Nome de um afluente do Rio Xingu cujas cabeceiras nascem na Serra do Roncador. O limite sul original da fazenda, situada no interflúvio Araguaia/Xingu, ia até o Rio Suiá Missú.
} 
A selvageria dos grandes empreendedores do Araguaia foi denunciada e combatida pela Prelazia de São Félix do Araguaia, comandada pelo célebre bispo Pedro Casaldáliga, um dos fundadores do Conselho Indigenista Missionário (CIMI), que foi perseguido pela ditadura militar por sua atuação em prol de índios e posseiros da região, incluindo processos de retomada de territórios (ESCRIBANO 2000; RODRIGUES, 2013b).

No caso de Marãiwatsédé, Ariosto da Riva, ex-garimpeiro que ficou conhecido na imprensa como o "último dos bandeirantes", adquiriu 484.000ha na região (BRANFORD; GUCK, 1985) com o objetivo de instalar um projeto de colonização, mas logo desistiu da empreitada ao constatar a baixa qualidade do solo e, em 1961, se associou ao Grupo Ometto, da indústria sucre-alcooleira de São Paulo. Nasceu então a Agropecuária Suiá-Missú, com $80 \%$ da propriedade pertencente ao Grupo Ometto, que na década de 70 se tornou o maior produtor de álcool do mundo. Ariosto da Riva acabou se desfazendo da sociedade com os Ometto para implantar projetos de colonização no Mato Grosso, dando origem às cidades de Alta Floresta e Apiacás, entre outras. Os Ometto expandiram a Fazenda Suiá Missú para uma gigantesca área de 786.000 ha após a transferência dos índios de Marãiwatsédé e expulsão dos pequenos posseiros, tornando-se o maior projeto apoiado pela SUDAM.

Nessa época, Raimundo Aleixo Borges já morava no Rio das Mortes e veio de lá para trabalhar na abertura de picadas da Fazenda Suiá Missú. Ele lembra que a sede da fazenda foi instalada no local chamado de "Boca da Mata", por ser justamente o limite de transição entre o cerrado e a área de cerradão, de mata mais densa, que se iniciava a partir dali, e que também era utilizada pelos Xavante em suas expedições de caça e coleta7. Aos poucos, a fazenda foi se apropriando de terras de posseiros que já estavam na região.

Em 61 eu vim lá do Rio das Mortes para trabalhar na Suiá, em agosto de 61. [...] Nessa época eu tinha 15 anos de idade, eles até não queriam me aceitar porque

\footnotetext{
${ }^{7}$ O Professor da UnB George Eiten $(1970,1975)$, que fez pesquisa sobre a vegetação da Serra do Roncador em 1968 e 1969, demonstra que esta área situa-se em uma faixa de transição entre o cerrado e a floresta amazônica, um tipo de "cerradão" que contém padrões dos dois tipos de vegetação, desfazendo-se assim a oposição rígida entre "cerrado" e "mata" que os invasores da Fazenda Suiá Missú usaram para argumentar que ali não era território xavante, pelo fato dos Xavante supostamente serem um povo de "cerrado" apenas (ver RODRIGUES, 2004).
} 
eu era muito pequeno. Depois aceitaram, porque eu ia junto com o meu tio. Nós entramos ali para dentro e fizemos essa parte aqui todinha [o limite sul], passamos 5 meses. [...] Eu saí daqui de dentro (da mata) mais ou menos no dia 28 ou 29 de dezembro. O engenheiro que a gente foi, que mexia com isso, chamava Júlio. Era um italiano. O dono era esse Ariosto, tem o Abelardo e outro que eu não lembro o nome. [...] Mas esse Ariosto todo mês ele estava lá. Ele ia até o campo de avião. Aonde tivesse um campo de avião ele baixava. Ficava por lá um tempinho, tempo curto, e ia embora. [...] Saímos de lá em dezembro, quando nós amarramos a picada na beira do [Rio] Suiazão. [...] Depois ele estava começando a invadir as terras para cá, dos posseiros, sabe? O campo aqui, essa região toda deles, estavam invadindo. Aí veio uma reclamação lá e voltaram tudo. Por isso que esses moradores que moravam nessa região toda aqui, [rios] Gameleira, Azulona, Xavantinho... [...] O pessoal que morava nessa região aqui, onde fica o tal do [Alto] da Boa Vista que você falou, esse pessoal foi todo embora, quase tudo para o Pará, por conta da Suiá estar invadindo, dizendo que as terras eram dela. [...] Começou a invadir a parte do cerrado. Já estava lá embaixo. Os índios já tinha expulsado, porque os índios já estavam lá no Tapirapé. Aí começou a expulsar os posseiros. O pessoal ficava com medo e ia embora. Aí foi que veio a ordem não sei de onde e fez a Suiá arrancar a cerca e mudar aqui parra a legítima divisa dela (BORGES apud RODRIGUES; FERRAZ; MAMPIERI, 1992, p. 33-35).

\section{A memória do apocalipse}

Rubens Valente (2017) aborda a história de Marãiwatsédé em seu importante livro, mas privilegia, no entanto, a versão mais suave contada pelos brancos em fontes documentais, como processos judiciais, omitindo fatos impactantes da narrativa dos próprios Xavante que viveram a experiência pessoalmente.

Foi na aldeia Monipa que o cacique Caetano Ruawé, o pai do atual Cacique Damião Paridzané, da Terra Indígena Marãiwatsédé, ouviu falar de Ariosto da Riva, por meio de uma proposta transmitida por seu sobrinho Tibúrcio, o então cacique de Ire'pa. Depois de muitos debates internos, liderados por Caetano, que desconfiava da proposta, e Tibúrcio, que deu um crédito de confiança a Ariosto, os Xavante tiveram que 
escolher entre continuar uma guerra cada dia mais suicida ou estabelecer relações pacíficas, aceitando então a proposta de se mudar para uma nova aldeia próxima da sede da fazenda, nomeada Wede'omo're (espinho vermelho abundante no lugar). Raimundo Borges estava na fazenda no dia da mudança de um dos grupos.

A Suiá pediu para a gente não atirar nos índios, não espantar eles de jeito nenhum, agradar eles. Que desse tudo para eles, açúcar, comida, o que eles quisessem, que desse. Até roupa, que desse para eles, ela nem cobrava da gente. A gente tinha roupa por conta deles. Até que ela foi domando esses índios aqui. [...] A primeira vez que eu vi eles mesmo, pessoalmente assim, foi quando começou a Suiá. Aí perto de onde era a sede, no primeiro campinho que foi feito, que eles fizeram as barraquinhas deles lá para ir caçar. Eles já não eram muito bravos. [...] Quando os índios concordaram de ir para lá, já tinha muito gado. Foi em 63 mais ou menos que os índios foram para lá. Depois passaram pouco tempo lá. Mudaram eles para o Rio Tapirapé, mas depois que esses lá já tinham convencido essa aldeia do Roncador ir para lá. O dia da mudança deles, dos outros bravos, eu estava lá, na Suiá. Os mais mansos já estavam lá. Foram eles que vieram e levaram os outros. Chegaram a pé, tudo carregando as coisas nas ... as mulheres faziam a mudança, eles tudo pintado e pelado. Só pintado e com os arcos e flechas na mão. Eles não conversavam, só conversavam com os outros mesmo. Só os índios mansos é que conversavam com eles. Eles passaram direto para a sede, para a sede assim, passaram direto para a aldeia. E ficaram para lá. Esses outros já tinham as casas. Aí fizeram mais casas lá. Quando eles fizeram as casas lá, passaram um tempo, uma temporada, aí a Suiá pegou eles todos e levou para o Rio Tapirapé. [...] [ $\mathrm{Na}$ aldeia perto da sede] continuaram caçando, a Suiá matava gado para eles. [...] Eles faziam as festas deles lá, mas a gente não podia ir lá não. Ia, mas não era permitido pela Suiá a gente ir lá não (BORGES apud RODRIGUES, FERRAZ, MAMPIERI, 1992, p. 35-37).

Organizados historicamente pelo princípio social da reciprocidade, os Xavante entenderam que a proposta era uma "troca", embora tenha se transformado na prática em uma traição: os índios recebiam mantimentos e ferramentas, permanecendo no lugar, e ajudavam no trabalho da fazenda. Tibúrcio acreditava que a "ajuda" de Ariosto seria importante 
para eles "manterem o lugar para sempre [...]. Ninguém sabia que era em troca da terra, ninguém cismava disso" (RODRIGUES; FERRAZ; MAMPIERI, 1992, p. 57). Segundo Paulo César Xavante, tradutor do Grupo Técnico da Funai, "Ariosto fez essa proposta para Tibúrcio, mas tudo em troca de mantimento e comida, para eles tomarem conta das terras indígenas. Ninguém sabia que era para sair daqui" (RODRIGUES; FERRAZ; MAMPIERI, 1992, p. 58). Ariosto enviou um trator e um caminhão para ajudar na mudança e todos os Xavante dispersos em outras aldeias se juntaram em We'de'omo're por volta de 1962, segundo essa memória, onde julgaram que estariam seguros.

$\mathrm{Na}$ nova aldeia, Caetano Ruawé decidiu transmitir a liderança do povo de Marãiwatsédé para Tibúrcio. Os Xavante, que em sua maioria não falavam português, foram rapidamente incorporados como peões da fazenda, trabalhando na abertura de pistas de aviões, de roças e no desmatamento de áreas para pasto:

Olha, foi trabalhando como empregado, como escravo, morreu muita gente. Trabalhando sem receber dinheiro, sem ganhar nada, sem assistência de saúde nenhuma. [O Ariosto] só dando comida, arroz limpo. Não é arroz inteiro, é quebradinho. Aí fizeram roça, abriram esse campo, a pista da sede, abriram [...] picada, tiraram madeira, puxaram com caminhão. [...] Tudo esparramado, trabalhando (PARIDZANÉ apud RODRIGUES; FERRAZ; MAMPIERI, 1992, p. 59).

As pressões aumentavam dia a dia, e com a chegada de um novo gerente da fazenda, tornaram-se insuportáveis, obrigando os A'wuê a se mudar para um lugar distante, a mais de $20 \mathrm{~km}$, e muito inferior, na região do Rio Tapirapé, fora dos limites da imensa propriedade. O novo lugar, nomeado como U'bre'hu ("cabaça" abundante no local), situava-se em área de várzeas ("varjão", termo regional) de solo pobre, arenoso e inundável.

O gerente do Ariosto não gostava de índio. [...] O último gerente era Maurício. Não gostava. Logo que ele assumiu, queria mandar [a gente] embora. Logo que assumiu, uns quinze dias depois, primeiro jogou (o gado) para judiar a roça do índio. [Jogou] o gado na roça. [...] Depois fizeram arame para cercar (a aldeia), para o índio não passar na fazenda. Terceiro, chegou comentário. Aí 
Maurício já está andando com cavalo até lá na estrada da aldeia We'de'omo're, logo lá na cerca, andando armado (PARIDZANÉ apud RODRIGUES; FERRAZ; MAMPIERI, 1992, p. 59).

Dario Carneiro, funcionário do Grupo Ometto, é lembrado pelos Xavante como alguém que os ajudou naquela época. Segundo seu depoimento à Justiça Federal (VALENTE, 2017, p. 27), ele chegou à fazenda aos 23 anos, onde se interessou pelos Xavante, aprendeu a se comunicar com eles e foi encarregado de resolver os "problemas" dos índios. Segundo Damião, ele teria avisado a Tibúrcio naquela época sobre as intenções do gerente e de Ariosto:

Dario estava a favor do índio. Quando ele ficou sozinho, contou, avisou Tibúrcio: "Tibúrcio, o branco vai acabar com índio tudo, por isso que eu estou brigando, eu quase matei o cara, eu quero morrer a favor do índio. Agora você pensa, pensa direito, eu quero que você retire o índio daqui, foi Ariosto que autorizou o gerente, que deu ordem para dar uma prensa, para ficar em cima do índio até sair. Foi Ariosto". O índio não quis, o Tibúrcio não quis. Que aconteceu? Ariosto pensou: "agora eu vou jogar lá onde é o limite da fazenda, onde tem varjão". O Maurício sempre ficava em cima para sair, falando que ia acabar com o índio, ameaçando. Aí pessoal ficou desanimado, com medo também (PARIDZANÉ apud RODRIGUES; FERRAZ; MAMPIERI, 1992, p. 61).

Em suas memórias, Raimundo Borges corrobora a influência de Dario na vida dos Xavante e a pressão crescente da fazenda. Com uma imensidão de área em seu poder, o proprietário e o gerente decidiram soltar o gado justamente na roça indígena.

Tinha o Dariozinho, um baixinho. Ele que ajeitava todo o negócio dos índios. Ele fazia como se fosse um chefe deles, como se fosse um gerente deles. Eles tinham o cacique deles lá, mas o Dariozinho que coordenava tudo. Pedia alguma coisa para eles para a Suiá, o que eles precisassem. Ele ia lá e dava para eles. Ele que levou eles para o Tapirapé. A roça deles não era lá na aldeia, a roça deles era aqui dentro, na [mata]. A Suiá fez a derrubada e marcou um pedaço lá para eles plantarem as coisas deles. Um determinado pedaço, falou: "isso aqui é de vocês, só para vocês plantarem". E depois jogou o capim. Quando o capim formou, ela jogou o gado, estragou a roça deles também. Lembro direitinho. 
A Suiá plantou arroz e eles plantaram milho, plantaram tudo. Quando a Suiá colheu arroz, eles usaram o [capim] colonhão que eles tinham para o gado. Soltaram o gado lá dentro. Logo depois disso, eles foram embora (BORGES apud RODRIGUES; FERRAZ; MAMPIERI, 1992, p. 38).

Há também uma memória de assédio sexual dos peões da fazenda em relação às mulheres Xavante, apesar da proibição de Dario Carneiro, que não permitia que os funcionários fossem até a aldeia.

A gente ia lá, mas ia escondido dele. Tinha muito peão, peão ia lá escondido. [...] O costume dos índios é outro, chegava lá e o peão se metia com o pessoal deles lá. [...] Isso eu ouvi dizer que tinha, mas só deles mexerem com as índias (BORGES apud RODRIGUES; FERRAZ; MAMPIERI, 1992).

Depois de várias reuniões entre os Xavante e "Dariozinho", que também teria sido ameaçado de morte pelo gerente, eles decidiram se mudar a contragosto, pois muitos não queriam, como Caetano Ruawé, sabendo que seria para um lugar pior. Dario arrumou um burro para levar comida para os homens, que partiram para plantar uma roça no novo local, quinze dias antes das mulheres e crianças.

A mulherada foi [depois], largaram muita coisa, milho, batata, abóbora, porque não tinha jeito de carregar, não tinha carro. Então eles levaram comida, largaram casa, mudaram para lá, [...] fundaram aldeia. Era ruim! Cheio de água, no tempo da chuva é cheio de água! Dormiram em cima da cama, mas a água sempre subindo, e nem acende fogo, ninguém comia. Tudo molhado! (PARIDZANE apud RODRIGUES; FERRAZ; MAMPIERI, 1992, p. 61).

Os Xavante foram jogados no varjão das planícies inundáveis do Araguaia e afluentes, que permanece inabitável durante vários meses por ano, onde mal podiam dormir ou acender fogo na estação cheia. No tempo em que viveram em U'bre'hu, cerca de um ano e meio, sofrendo privações alimentares e desconfortos de toda ordem, a situação ficou insustentável, a ponto de Ariosto mandar construir outra pista de avião nas proximidades de aldeia para enviar alimentos. 
Quando encheu de água dentro da casa, eles foram para o campo de aviação, que tem cascalho. Foi Tibúrcio que mandou fazer a pista no meio do cascalho. Fizeram e mudaram de novo. Ariosto mandou a comida de avião. Repartiram. Aí começa dar tristeza, judiando... e sofremos também. Nós, quando éramos pequenos, sofremos! Passando fome, não tem campo, mata, mas só varjão mesmo. E cerrado de cascalho. (PARIDZANÉ apud RODRIGUES; FERRAZ; MAMPIERI, 1992, p. 62).

Essa mudança para as proximidades do Rio Tapirapé teria ocorrido no final de 1964, conforme a memória de Raimundo Aleixo Borges.

Quando eles saíram daqui, já estava tudo tomado de posseiro, mas eles ainda viviam por aí. No final de 64, mais ou menos. O certo é que a Suiá queria se ver livre deles perto da sede. Ela apelava para isso, dizia que não queria que os peões fossem lá perturbar os índios. Aí mudou eles lá para o [Rio] Tapirapé. A mudança deles para lá eu não vi não. No começo eles não queriam ir não. Eles queriam vir para cá, mas a Suiá queria levar eles para lá, porque para lá não tinha muito recurso para eles. Eles queriam voltar aqui para a Serra do Roncador, para a beira do [córrego] Grotão, aí para cima. Mas aí já estava tudo tomado de gente, já estava cheio de morador, de fazendinha, posseiro. Eles não queriam ir para lá porque o terreno não era muito adequado para eles. Mais certo era onde eles estavam, onde eles moravam, para a Serra do Roncador, para cima da Serra do Roncador. Para a cabeceira do [córrego] Gameleira, onde era a aldeia velha deles. [O Rio] Tapirapé é um lugar que só tem varjão, muito alagado. Eles não queriam ir para lá, porque não é o lugar ideal deles. Eles são de onde tem caça. Eu ouvi dizer que eles começaram a reclamar, começaram a achar ruim, porque lá eles estavam dependendo da Suiá. A Suiá que levava toda a alimentação deles. Eles tinham como caçar, mas não era como nas cabeceiras do Grotão. Para alimentar, eles tinham que depender da Suiá. Quando eu saí da Suiá, eles ainda estavam na beira do Tapirapé (BORGES apud RODRIGUES; FERRAZ; MAMPIERI, 1992, p. 39).

Mais de dez adultos teriam morrido em razão de doenças e falta de água potável no lugar ${ }^{8}$. Diante da situação de penúria, Dario Carneiro teria obtido de Ariosto da Riva a permissão para procurar outro local para os

\footnotetext{
${ }^{8}$ Depoimento do padre salesiano Bartolomeo Giaccaria à $5^{\text {a }}$ Vara Federal de Mato Grosso (apud VALENTE, 2017, p. 27).
} 
A'wuê fora da fazenda. Os índios estavam certos de que a mudança seria para a região da antiga aldeia Bo'u, que havia ficado fora dos limites da fazenda. No entanto, estava em curso um acordo de bastidores com outro propósito entre os proprietários da fazenda, o SPI, os padres salesianos e a FAB.

Em seu relato detalhado daqueles dias que nunca foram esquecidos, Tibúrcio lembrou que ele entrou em um avião com Dario para procurar um novo lugar, sem saber que o avião ia direto para a distante aldeia Merure, dos Bororo. De lá os dois seguiram de carro para a Missão Salesiana de São Marcos, fundada em 1958 junto a outro subgrupo xavante, a mais de $500 \mathrm{~km}$ de distância ao sul de Marãiwatsédé. O diretor da missão, pe. Mario Ottorino Panziera, perguntou então a Tibúrcio se ele havia gostado do lugar e se queria mudar com seu o grupo para São Marcos. Um Tibúrcio acuado pelo histórico de opressões e falta de opções acabou cedendo.

Quando combinou com Dariozinho, ele perguntou para o Tibúrcio se poderia procurar uma terra para poder mudar de U'bre'hu, para poder retornar para Bo'u. O Tibúrcio ficou de acordo, "tudo bem, nós vamos, porque aqui não vai dar, o pessoal está com muita ameaça. [...] Eu sozinho não dou conta de defender. Então é melhor nós procurarmos, talvez tenha algum lugar no campo e a gente pode fazer aldeia fora da sede". Tibúrcio não sabia, nem ele avisou que ia para São Marcos. Aí o avião deu voo, saiu de Gorgulho [U'bre'hu]. Ele entrou e ficou de acordo, sem saber de nada, que ia para São Marcos. Entrou no avião e o avião voou direto. Primeiro foram só eles dois, o Tibúrcio e o Dario. O avião deu voo, não sei, era mais ou menos 4 horas, de tardezinha, aterrissou em Merure. De Merure foram direto para São Marcos. De São Marcos, lá perguntaram para o Tibúrcio se ele gostou da missão, para deslocar o pessoal de lá para cá. Tibúrcio ficou sem jeito, se podia vir ou não. Aí o pessoal, os padres, Padre Mario Panziera, que era diretor da Missão Salesiana em São Marcos, convidou o Tibúrcio se poderia vir. Que aconteceu? O Tibúrcio ficou sem jeito, mas assim mesmo entrou de acordo. Por quê? Porque os padres sabiam que o pessoal já estava com processo para ser expulso (XAVANTE, Paulo César traduzindo TIBÚRCIO apud RODRIGUES; FERRAZ; MAMPIERI, 1992, p. 62-63). 
O SPI não fez nenhum movimento para garantir a permanência dos Xavante em Marãiwatsédé. Pelo contrário. A transferência em 1966 teria sido articulada pelos proprietários da fazenda com figuras importantes do indigenismo na época, como os sertanistas Orlando Villas Bôas, que estava atuando na transferência de outros povos para o Parque Indígena do Xingu, e Francisco (Chico) Meireles, o "pacificador" dos Xavante, além do inspetor Ismael Leitão. A remoção foi autorizada formalmente em 11 de julho de 1966 por Nilo Oliveira Vellozo, chefe do Setor de Assistência ao Índio (SASSI) do SPI em Brasília (VALENTE, 2017, p. 27-28). Em 1970, Cláudio Villas Bôas deu seu aval a uma certidão negativa da Funai atestando a inexistência de índios na fazenda (ROSA, 2015).

Orlando Villas Bôas também exigiu para tirar o pessoal daqui. O pessoal do SPI que fez o documento, foram eles que queriam que o pessoal fosse acabado aqui dentro. 0 Orlando Villas Bôas, aquele Ismael [Leitão] e o Chico Meireles. São esses a equipe que queria, que exigiu para acabar com índio. O Orlando Villas Bôas veio aqui na sede, só ele, conversar com Ariosto e com Tibúrcio. O Tibúrcio poderia tirar logo o pessoal para São Marcos. Então ficou sem jeito. Como que ia dar força para o pessoal segurar aqui? Ele também já estava com medo de não perder o pessoal aqui. [...] O Chico Meireles não veio, porque já estava combinado que vinha um, o Orlando que veio. [...] Não era como agora, que a Funai está tendo muito apoio para o índio. Mas tem alguns também que não são de confiança, nem dá para confiar. Naquele tempo de SPI, ninguém avisou, ninguém ficou a par para não sair, para não deslocar. Ninguém do SPI falou: '- nós não devemos retirar os índios daqui, tem que permanecer aqui'. Ninguém ficou a favor. Só o Dario que ficou apoiando (XAVANTE, Paulo César traduzindo TIBÚRCIO apud RODRIGUES; FERRAZ; MAMPIERI, 1992, p. 63).

Os missionários salesianos também foram envolvidos porque já atuavam em outras comunidades xavante desde a década de 1950 e havia um projeto em andamento do pe. Pedro Sbardellotto para fundar uma missão em Marãiwatsédé, o que foi descartado com a decisão da transferência. Os Xavante lembram que o pe. Pedro foi avisado da decisão na última hora e protestou junto ao SPI e ao pe. Mario Panziera contra a transferência, prevendo que os índios iriam retornar um dia ao seu território. 
Esse padre, antes do Tibúrcio ir para lá, para São Marcos, esse padre Pedro também queria fundar a missão lá em Bo'u. Já estava com um processo com o Inspetor para fundar a missão lá em Bo'u, no centro. O Padre Pedro também ficou sabendo na última hora que o pessoal já estava para ser deslocado para São Marcos. Aí entrou na Diretoria ou lá na Inspetoria e saiu de lá magoado, chorando, porque os índios iam ser expulsos de lá. O Padre Pedro falou: "se eu já entrei com todos os processos para fundar a missão, por que vocês querem retirar os índios de lá?". O pessoal respondeu: "a ordem é essa, a ordem é para retirar até São Marcos, ninguém vai passar por cima disso". Aí o Padre Pedro ficou mais preocupado. Depois ele veio conversar com o Padre Mário Pansiera. [...] "Padre Mario, como que ficou esse acordo?". [Mario:] "O acordo que ficou é para retirar os índios de Marãiwatséde". [Pedro:] "E por que vocês fizeram isso, se vocês já tinham entrado em acordo, por que vocês não me avisaram antes disso? O que foi feito, tudo bem, eu não vou te falar nada agora. Você é diretor daqui, eu não vou convencer você, mas eu vou te falar. Se algum dia, ou talvez depois, se você está deslocando esse pessoal, um dia você vai se arrepender. Alguém se prepare para esse retorno, pode não ser agora, mas vai acontecer". Falou isso para o Padre Mario e é o que está acontecendo agora (XAVANTE, Paulo César traduzindo TIBÚRCIO apud RODRIGUES; FERRAZ; MAMPIERI, 1992, p. 64).

Em seu depoimento à Justiça Federal, o Padre Mario Ottorino Panziera revelou que as decisões foram tomadas por altos escalões do governo federal.

\begin{abstract}
Panziera esteve em conversas frequentes com 0 empresário Hermínio Ometto e ambos decidiram recorrer à ajuda de aviões da Força Aérea Brasileira $(F A B)$. Foram ao Rio de Janeiro, onde falaram com ninguém menos que o ministro da Aeronáutica, brigadeiro Eduardo Gomes, que consultou sua assessoria e autorizou o transporte. Na primeira viagem, o avião da FAB levou 54 índios, entre adultos e crianças. [...] As demais viagens ocorreram entre uma semana e dez dias depois da primeira (VALENTE, 2017, p. 29).
\end{abstract}

Antes dos voos, os Xavante discutiram internamente mais uma vez sobre a proposta, que não era consensual. 
Tibúrcio voltou para combinar com o pessoal se podia deslocar para São Marcos. Ele não sabia o que ia acontecer. Os velhos se reuniram, alguns não queriam ir, alguns queriam ir para lá. O pai do Damião, ele não queria que retirasse o pessoal de lá. Queria ficar, porque ele sabia que ia acontecer alguma coisa de doença. Então o que aconteceu? O pessoal veio de lá de U'bre'hu para cá [a sede] ainda a pé, aqui no campo de pouso. Vieram a pé para cá para pegar o avião. As pessoas ficaram de acordo, todo mundo entrou de acordo sem boa vontade (XAVANTE, Paulo César traduzindo TIBÚRCIO apud RODRIGUES; FERRAZ; MAMPIERI, 1992, p. 64).

Tomada a decisão e pressionada pela fome e pelo medo, a comunidade de U'bre'hu realizou penosa jornada de retorno para a sede da fazenda para embarcar nos aviões. Em sua recente dissertação de mestrado, Cosme Rite, filho de Damião Paridzané, relata que os "A'uwê Marãiwatsédé" foram avisados pelos espíritos da Casa dos Homens da tragédia iminente.

Os fazendeiros e missionários iniciaram um processo para tentar nos convencer de abandonar nossas terras e ir para o território de outros Xavante. Os missionários falavam que se continuássemos na nossa terra, os fazendeiros iriam matar todos. [...] Dois dias antes de a aeronave chegar, houve um ritual wai'a (de iniciação dos meninos, o poder da espiritualidade dos homens). [...] Quando amanheceu, os A'uwê ouviram um barulho da aeronave. [...] Na porta do avião, houve uma discussão entre jovens A'uwê que não queriam entrar na aeronave. [...] Naquele momento, na entrada do avião, os jovens guerreiros reproduziram a voz da espiritualidade afirmando que a partir daquele momento, muitos iriam morrer, prevendo o nosso destino, e foi o que aconteceu. Não há fotos do nosso embarque na aeronave, eu penso que elas foram destruídas, só há fotos do nosso desembarque na Terra Indígena de São Marcos. Foram cinco voos até São Marcos, levando todos os A'uwê Marãiwatsédé. Com o último embarque acabou tudo, acabou a autonomia (RITE, 2017, p. 23).

A recepção na Missão São Marcos não poderia ter sido mais catastrófica. Circulava na aldeia uma epidemia de sarampo, para a qual os A'wuê de Marãiwatséde não tinham nenhuma imunidade. 
Cento e sessenta. O Padre Pedro falou "cento e pouco". Mestre Mario falou em Cuiabá também que foi cento e cinquenta. [...] Meu pai, logo que chegou, pegou a doença e ficou sofrendo dois dias de sarampo. Aí começaram a morrer muitos. Meu pai morreu dois dias depois. Daí começou, noite toda, dia todo, carregaram [os corpos] na carroceria do trator, levaram no cemitério para enterrar. Noite toda, dia todo. Crianças morrendo, todas. Nem passaram 15 dias! [...] Morre, mas junta. Trator encosta e padre manda: "encosta lá, lá está morrendo já". Aí a gente botando em cima da carroceria e lavando onde que tem cemitério. Está tudo enterrado lá em São Marcos. Escapou pouca gente (PARIDZANÉ apud RODRIGUES; FERRAZ; MAMPIERI, 1992, p. 65).

Depois que chegou aqui, com dois dias o pessoal já estava de sarampo quando chegou em São Marcos. Morreu muito, morreu bastante. Adultos, velhos (XAVANTE, Paulo César traduzindo TIBÚRCIO apud RODRIGUES; FERRAZ; MAMPIERI, 1992, p. 64-65).

Isso que dá tristeza! Quando lembro assim, à noite, ainda incomoda muito. [...] Meu pai chegou na missão bem de saúde, meu irmão chegou bem de saúde! Depois de um dia pegou a doença e morreu em dois dias (PARIDZANÉ apud RODRIGUES; FERRAZ; MAMPIERI, 1992, p. 65).

Uma reportagem do Diário da Noite, jornal paulista, de 14 de setembro de 1966, cerca de um mês depois da transferência, feita pelos jornalistas após visita à Missão São Marcos, revela que a epidemia de sarampo tornou impossível a recepção festiva que os 510 indígenas do lugar haviam preparado para os 236 novos habitantes procedentes da Fazenda Suiá Missú. Na ocasião da visita dos jornalistas, já haviam morrido 64 pessoas e o pe. Mario Panziera orava a Deus, na beira de uma sepultura.

Não foi num dia alegre que se deu sua chegada. No pequeno campo [de pouso], não encontraram um irmão de tribo. Pelo caminho, foram vendo os outros xavantes caídos sobre esteiras de capim-colônia ou tombados sobre montes de terra vermelha. Era a inanição e a morte quem os recepcionava. [...] Dez dias após a chegada do grupo que viera da Serra do Roncador, já existiam 434 indígenas doentes na missão de São Marcos. Dos dois grupos, o que já habitava o lugar e o que viera depois, apenas 312 índios haviam conseguido 
fazer frente à doença (ALVES; CARDOSO; ROCHA, 1966) $)^{9}$.

A reportagem, intitulada "Morte é recepcionista na aldeia dos Xavantes", enaltece o heroísmo de padres, irmãs e índios que lutaram para combater a epidemia, mas revela de modo incontestável que os índios de Marãiwatsédé foram levados para um lugar onde já estava circulando havia vários dias ou semanas uma epidemia mortal de sarampo, atribuída a um branco que visitara a aldeia um mês antes. Em seu depoimento no processo judicial décadas depois, o pe. Mario Panziera estimou que tenham morrido entre 140 e 160 do total dos dois grupos da missão (VALENTE, 2017, p. 30). Já o pe. Bartolomeo Giaccaria calculou em 100 pessoas o número de mortos de Marãiwatsédé, ou seja, quase a metade do grupo.

A reportagem do jornal paulista confirma o depoimento dos próprios A'uwê de Marãiwatsédé, de que já havia um surto em andamento no momento da chegada, e evidencia desconfortavelmente que houve grave negligência e omissão, para dizer o mínimo, dos agentes responsáveis pela transferência, que não pouparam os índios de uma tragédia anunciada. Para agravar mais ainda a situação, os Xavantes se lembram de que, em meio ao caos da epidemia, os salesianos encaminharam crianças para local desconhecido sem a autorização das famílias, as quais nunca mais foram vistas. Uma delas era a prima de Paulo César Xavante, atual cacique da aldeia Belém, na Terra Indígena Pimentel Barbosa.

Levaram três crianças, mandaram três crianças. Pode ser a freira, a irmã, o padre que resolveu. Mandaram quatro, sumiram três crianças ... quatro, foram quatro. [...] Não sei, acho que foram para Campo Grande. Foi padre que liberou para levar menino (DAMIÃO PARIDZANÉ apud RODRIGUES et al, 1992, p. 65).

O trauma imensurável que tudo isso causou ainda não foi assimilado pelos A'uwê. Em seu impactante Parecer Técnico Psicológico para o MPF em 201610, após uma série de entrevistas com a comunidade, o psicólogo conclui que a remoção forçada, seguida de mortes em grande

\footnotetext{
${ }^{9}$ Ano XLII, N. 12.768.

${ }^{10} \mathrm{~N}^{\circ}$ 2766-51.2016.4.01.3605, Justiça Federal de Barra do Garças (MT).
} 
quantidade e a perda do território de origem, desencadeou "traumatização psicossocial coletiva" em um processo cumulativo que atingiu as gerações atuais.

A imagem dos corpos amontoados nos caminhões sem nenhum cuidado aparece com frequência. A preparação do corpo, o preparo da cova e o choro ritual, para depois haver o sepultamento, foram substituídos por um enterro coletivo, sem ter sido cumprido nenhum tipo de ritual. E o preparo da cova, pensada em um espaço especifico e preparada segundo a cultura Xavante, foi substituído por uma vala única, um "buraco" feito em algum lugar, sem nenhum cuidado na escolha, do ponto de vista da ritualidade Xavante. O recolhimento dos corpos e seu enterro coletivo em vala comum são o ápice do processo da violência que desencadeou a traumatização nessa população. [...] É como se não houvesse palavra certa para descrever o horror da experiência de ver seus parentes sendo jogados de cima do caminhão em uma vala comum. A morte coletiva dessa magnitude não é prevista pela cultura Xavante. É um acontecimento que não pode ser elaborado por algum aspecto pré-existente na própria cultura. [...] Além do terror da remoção e da morte coletiva, a desumanização extrema do enterro em vala comum, sem qualquer cuidado, intensificou ainda mais a magnitude do sofrimento psíquico dos Xavante. A falta absoluta de qualquer cuidado ritual representa uma desordem cósmica muito difícil de ser restabelecida. Ignorar a complexidade social Xavante em sua relação com seu mundo espiritual já seria um fator desestruturante em momentos menos graves. Como demonstram estudos (Deluci, 2013 e Ru'a, 2012), a imposição e interdição de ritos afeta diretamente o universo socioafetivo dos Xavante. No episódio em análise, a intensidade dessa desestruturação alcança níveis devastadores (GONÇALVES, 2016) ${ }^{11}$

Como resultado desse processo criminoso e genocida de remoção de um povo, que beneficiou exclusivamente grandes grupos econômicos e um modelo predador de relação com a terra e seus recursos, e cujos mentores nunca foram responsabilizados, os sobreviventes de Marãiwatsédé vivenciaram uma forte desestruturação interna com a morte de importantes líderes. O grupo passou a viver disperso em várias aldeias

${ }^{11}$ Ação Civil Pública Nº 2766-51.2016.4.01.3605, Justiça Federal de Barra do Garças (MT). 
xavante, como hóspedes indesejados, em um humilhante e conflituoso périplo que durou décadas. Mesmo assim, os A'wuê continuaram realizando expedições anuais a Marãiwatsédé durante todos esses anos, mantendo o vínculo e sonhando com o retorno a seu território tradicional.

O retorno foi alcançado depois de um esforço incansável e persistente, mas para uma terra devastada, cercada de uma população que em sua maioria teme e rejeita os Xavante, que agora estão em busca da reconstrução possível de uma vida coletiva, digna e em seus próprios termos.

\section{Referências bibliográficas}

ALENCASTRE, José Martins Pereira de. Annaes da Província de Goyaz. Revista Trimensal do Instituto Histórico, Geographico e Ethnographico do Brasil, Rio de Janeiro, tomo 27 5-186, p. 229-349, 1864.

ARTIAGA, Zoroastro. Dos índios do Brasil Central: trabalho organizado por força de imposição legal contida no Decreto-lei que criou o Departamento Estadual de Cultura do Estado (de Goiás). Uberaba: Estabelecimento Gráfico Triângulo,1959 [1947].

AURELI, Willy. Roncador. São Paulo: Leia, 1962a [1939].

Bandeirantes d'Oeste. São Paulo: Leia, 1962b [1952].

BUENO, Inês Rosa. Laudo Antropológico Terra Indígena Marãiwatsédé. In: Ação Civil Pública N. 950000679-0/MT, 2006.

BRANFORD, Sue; GLUCK, Oriel. The last frontier: fighting over land in the Amazon. Londres: Third World Books, 1985.

CARSODO DE OLIVEIRA. A situação atual dos Tapirapé. Boletim do Museu Paraense Emilio Goeldi, Belém, Nova Série, n. 3, jul. 1959.

COMISSÃO NACIONAL DA VERDADE. Relatório: Volume 2, Textos Temáticos. 2014.

CRUZ MACHADO, Antônio Cândido. Relatório que à Assembléia Legislativa Provincial de Goyaz apresentou na sessão ordinária de 1855 o Exm. Presidente da Província Antonio Cândido da Cruz Machado" In: Memórias Goianas 6: relatórios dos governos da Província de Goiás, 1854-1856. Goiânia: UCG, 1997 [1855]. 
DELUCI, Luciana Akeme Sawasaki; PORTELA, Cristiane de Assis. Marãiwatsédé: memória de luta, resistência e conquista. In: SIMPÓSIO NACIONAL DE HISTÓRIA., 27, 2013. Anais... Natal: UFRN, 22-23 jul. 2013.

DUROURE, J. Sur la fleuve de la mort. Paris: EmmanuelVitte Editeur, 1936.

EITEN, George. A vegetação da Serra do Roncador (Resumo). Caderno de Ciências da Terra, São Paulo, n. 5, p. 5-9, 1970.

135, jul. 1975.

The vegetation of the Serra do Roncador. Biotropica, EUA, v. 7, n. 2, p. 112-

ESCRIBANO, Francesc. Descalço sobre a terra vermelha. Campinas: UNICAMP, 2000.

ESTERCI, Neide. Conflito no Araguaia: peões e posseiros contra a grande empresa. Petrópolis: Vozes, 1987.

FERRAZ, Iara. Dossiê Brasil: responsabilidades italianas na Amazônia. Brasília, 1990.

FERRAZ, Iara; MAMPIERI, Mariano. Um mito refeito. In: RICARDO, Carlos Alberto (Org.). Povos Indígenas no Brasil: 1991-1995. São Paulo: ISA, 1996. p. 675-678.

FERREIRA, João Carlos Vicente. Mato Grosso e seus municípios. Cuiabá: Buriti, 2001.

LIMA FILHO, Manuel Ferreira. O desencanto do oeste. Goiânia: UCG, 2001.

MAYBURY-LEWIS, David. A sociedade Xavante. Rio de Janeiro: Francisco Alves, 1984 [1967].

PINHEIRO, Paulo. Missão Carajás. Tatuí: Casa Publicadora Brasileira, 1994.

RITE, Cosme. Uso do território a partir do modo de ser A'uwê Uptabi Marãiwatsédé - Ti'a na dahoimanadzé Wahi'rata nori tsi Marãiwaitsété hoimandzébdzo hã. 2017. 83

f. Dissertação (Mestrado Profissional em Sustentabilidade junto a Povos e Territórios Tradicionais) - Centro de Desenvolvimento Sustentável, Universidade de Brasília - UnB. Brasília: UnB, [2017].

RODRIGUES, Patrícia de Mendonça. Subsídios antropológicos para a contestação do laudo elaborado por Hilário Rosa sobre a Terra Indígena Marãiwatséde. In: Ação Civil Pública N. 950000679-0/MT. 2004.

Relatório circunstanciado de identificação e delimitação da Terra Indígena Javaé/Avá-Canoeiro. Brasília: Funai, 2010.

Relatório circunstanciado de identificação e delimitação da Terra Indígena Taego Âwa. Brasília: Funai, 2012. 
Os Avá-Canoeiro do Araguaia e o tempo do cativeiro. Anuário Antropológico, Rio de Janeiro, v. 38, n. 1, p. 83-131, jul. 2013a.

Relatório de reestudo de limites da Terra Indígena Tapirapé/Karajá. Brasília: Funai, 2013b.

RODRIGUES, Patrícia de Mendonça; FERRAZ, Iara; MAMPIERI, Mariano. Relatório de Identificação da Área Indígena "Marãiwatséde”. Brasília: Funai, 1992.

ROSA, Juliana Cristina da. A luta pela Terra Marãiwatsédé: povo Xavante, Agropecuária Suiá Missú, posseiros e grileiros do Posto da Mata em disputa. 2015. 328 f. Dissertação (Mestrado em História, Territórios e Fronteiras) - Programa de PósGraduação em História, Universidade Federal do Mato Grosso - UFMT. Cuiabá: UFMT, [2015].

SPÍNOLA, Aristides de Souza. Relatório apresentado pelo Ilmo. e Exmo. Sr. Dr. Aristides de Souza Spínola, Presidente da Província, à Assembléia L. Provincial de Goyaz, no dia 4 de março de 1880. Memórias Goianas 13: relatórios dos governos da Província de Goiás, 1880-1881. Goiânia: UCG, 2001 [1880].

TAFNER JÚNIOR, Armando Wilson. Expansão da fronteira agropecuária do oeste paulista para a Amazônia: a trajetória das famílias Ometto e da Riva e a colonização do norte mato-grossense. 2015. 243 f. Tese (Doutorado em Desenvolvimento Sustentável do Trópico Úmido) - Núcleo de Altos Estudos Amazônicos, Universidade Federal do Pará - UFPA. Belém: UFPA, [2015].

TAVARES, Paulo. Memória da Terra - mapeamento e análise do processo de despossessão e remoção do povo Xavante de Marãiwatsédé. In: Relatório pericial para o Inquérito Civil Público 1.20.004.000072/2014/82/MT. Brasília: Autonoma, 2017.

TILBOR Sekelj. Excursión a los indios del Araguaia (Brasil): Archivo para las ciencias del hombre. Runa, Buenos Aires, n. 1. p. 97-114. 1948.

TORAL, André de Amaral. Cosmologia e sociedade Karajá. 1992. 287 f. Dissertação (Mestrado em Antropologia Social) - Programa de Pós-Graduação em Antropologia Social, Universidade Federal do Rio de Janeiro - UFRJ. Rio de Janeiro: UFRJ, [1992].

VALENTE, Rubens. Os fuzis e as flechas: história de sangue e resistência indígena na ditadura. São Paulo: Companhia das Letras, 2017.

VILLAS BÔAS, Orlando; VILLAS BÔAS, Cláudio. A marcha para o oeste: a epopéia da Expedição Roncador-Xingu. São Paulo: Globo, 1994.

WAGLEY, Charles. Lágrimas de boas vindas: os índios Tapirapé do Brasil Central. Belo Horizonte: Itatiaia/São Paulo: EDUSP, 1988 [1977]. 
Recebido em: 31/05/2018 * Aprovado em: 13/12/2018* Publicado em: 29/12/2018 